\title{
Analisis Penilaian Risiko Program Kerjasama Pemerintah Badan Usaha (KPBU) pada Infrastruktur Jalan Tol
}

\author{
DALIMAN, HERMAN, OKA PURWANTI \\ Program Studi Teknik Sipil, Institut Teknologi Nasional Bandung \\ Email: dmandaffa@gmail.com
}

\begin{abstract}
ABSTRAK
Pentingnya ketersediaan infrastruktur yang memadai dalam keterbatasan sumber daya pemerintah, menuntut dikembangkannya mekanisme kerjasama pemerintah dengan badan usaha (KPBU). Sebelumnya hanya pemerintah yang menanggung segala risiko pada pembangunan infrastruktur, kini risiko bisa terbagi dengan badan usaha. Sejak awal risiko ini teridentifikasi oleh badan usaha sebelum kesepakatan KPBU dilakukan. Guna mengetahui bagaimana risiko yang menjadi beban badan usaha, maka penelitian ini dilakukan. Metode three box method digunakan untuk mendeskripsikan risiko tersebut. Mengacu pada alokasi risiko pada PT Penjaminan Infrastruktur Hasil penelitian menyatakan bahwa distribusi risiko pada setiap fase tahapan proyek berbeda. Faktor risiko tinggi pada fase prakonstruksi meliputi finansial dan desain, konstruksi dan uji operasi, pada fase konstruksi meliputi faktor finansial dan pada fase operasi dan pemeliharaan meliputi finansial dan kepemilikan aset. Langkah mitigasi digunakan untuk mengurangi bahkan menghilangkan potensi risiko yang ada.
\end{abstract}

Kata kunci: risiko, manajemen proyek, jalan tol, KPBU

\begin{abstract}
The importance of adequate infrastructure availability in the limitations of government resources, demands the development of government cooperation mechanisms with business entities (PPP). Previously only the government that bear all the risks to infrastructure development, now the risk can be divided with business entities. This risk should be identified from the beginning by the business entity before the PPP agreement is carried out. In order to find out how the risks are burdened by business entities, this research was conducted. The three box method is used to describe the risk. Referring to the risk allocation in PT Penjaminan Infrastruktur Indonesia, there are 11 risk faktors with 70 indikators following mitigation measures.

The results stated that the distribution of risk in each phase of the project stages is different. In the preconstruction phase, risk faktors with high risk levels were financial and design, construction and operating tests. In the construction phase, the risk faktor with a high level of risk is financial. In the operating and maintenance phase the risk faktors with high risk levels are financial and asset ownership. Mitigation measures are used to reduce and even eliminate potential risks.
\end{abstract}

Keywords:risk, project management, toll road, PPP 


\section{PENDAhUlUAN}

Dalam upaya mendorong penanaman modal dan pertumbuhan ekonomi, infrastruktur menjadi faktor penting untuk disediakan. Untuk mengimbangi keterbatasan kemampuan keuangan pemerintah, diperlukan skema Kerjasama Pemerintah dengan Badan Usaha (KPBU) yang dapat memberikan peluang bagi badan usaha untuk berperan dalam pembangunan khususnya infrastruktur. KPBU setidaknya mampu mengalihkan sebagian ataupun seluruh risiko pada suatu proyek (yang sebelumnya hanya bertumpu pada sisi pemerintah saja) kepada badan usaha.

Salah satu bentuk keseriusan pemerintah dalam menerapkan skema KPBU ditandai dengan adanya KPBU pada infrastruktur jalan tol. Beberapa skema KPBU pada infrastruktur jalan tol yang telah dilakukan diantaranya pada proyek Jalan Tol Cileunyi - Sumedang - Dawuan (Cisumdawu), Jalan Tol Balikpapan - Samarinda dan Jalan Tol Manado - Bitung, dimana ketiga ruas jalan tol tersebut menerapkan skema KPBU dengan struktur kombinasi konsensi penuh dan operation and maintenance (O\&M) hybrid atau supporting build operation transfers (SBOT) (PT. Penjaminan Infrastruktur Indonesia, 2017).

Untuk mengetahui bagaimana dan seberapa besar risiko KPBU pada sektor jalan tol, dilakukan dilakukan penelitian terkait tingkat risiko dengan menggunakan analisis deskriptif kuantitatif menggunakan metode three box method.

\section{KERJASAMA PEMERINTAH DAN BADAN USAHA (KPBU)}

Kerjasama Pemerintah dan Badan Usaha (KPBU merupakan bentuk berjasama antara badan usaha dengan pemerintah dalam mendukung ketersediaan infrastruktur bagi kepentingan umum yang sesuai dengan spesifikasi. Dalam hal ini, sebagian atau seluruh pembiayaan menggunakan sumber daya badan usaha dengan mempertimbangkan pembagian risiko diantara pihak-pihak terkait. KPBU diharapkan dapat menjadi peluang terciptanya kombinasi pembiayaan (hybrid financing) dimana terbentuk penggabungan potensi pembiayaan dari badan usaha. Skema pembiayaan/pendanaan yang inovatif (innovative financing scheme) diharapkan dapat mempercepat proses pembangunan infrastruktur infrastruktur (Yusuf, 2018).

PT. Penjaminan Infrastruktur Indonesia (Persero) atau Indonesia Infrasturcture Guarantee Fund (IIGF) merupakan Badan Usaha Milik Negara yang didirikan oleh pemerintah dalam rangka menyediakan penjaminan kepada badan usaha akibat risiko tidak terpenuhinya kewajiban finansial pihak pemerintah (PJPK) dalam kontrak KPBU yang dipicu oleh pelanggaran kontrak serta perubahan aturan dan perundangan (PT. Penjaminan Infrasrtuktur Indonesia, 2017).

Beberapa pihak yang terkait dalam struktur proyek dengan skema KPBU meliputi Penanggung Jawab Proyek Kerjasama (PJPK), Badan Usaha (BU), Pendukung aspek konstruksi dan operasi serta Pendukung aspek pembiayaan. Dalam hal ini, badan usaha lebih memprioritaskan faktor terkait kelembagaan dan operasional proyek (Syamshabrina, A.S dan Ariastita, P.G, 2017). Melalui KPBU, keahlian dan aset dari pihak pemerintah maupun swasta dapat bekerjasama menyediakan pelayanan kepada masyarakat (Riyanda, I, 2020). Dalam hal kesuksesan implementasi Kerjasama Pemerintah dan Badan Usaha, Estache (2014) dan Maramis, JB (2018) menyebutkan bahwa faktor yang menentukan adalah kemampuan pemerintah dalam pembiayaan meliputi kemampuan: (a) mengidentifikasi proyek yang akan dibiayai; (b) menetapkan karakteristik jasa; (c) menyepakati imbalan; (d) bekerja dengan kontrak yang detail; dan (e) berinvestasi dan penguatan kontrak. 
Struktur KPBU berdasarkan sifat pelayanan dan pembagian risiko meliputi struktur berbasis ketersediaan layanan dan penggunaan infrstruktur (availability-based dan usage-based PPP) serta kontrak operasi dan pemeliharaan (O\&M Contrac).

\subsection{Struktur KPBU Sektor Jalan}

Untuk infrastruktur jalan tol, digunakan skema KPBU berbasis penggunaan (Usage-Based PPP) dimana Badan Pengatur Jalan Tol (BPJT) dan Kementerian PUPR, atas nama Menteri, berperan sebagai PJPK. Adapun struktur KPBU pada sektor jalan meliputi:

1. Struktur Build Operate Transfer (BOT)

2. Struktur Operation and Maintenance (O\&M)

3. Struktur Kombinasi Penuh dan O\&M

4. Struktur Availability Payment (AP)

\subsection{Faktor Risiko Pada Proyek KPBU}

Risiko adalah sebuah ukuran dari probabilitas dan konsekuensi ketidaktercapaian suatu tujuan proyek yang telah ditetapkan. Secara konsep, risiko dapat didefinisikan sebagai fungsi dari ketidakpastian dan kerugian. Risiko meningkat seiring dengan ketidakpastian dan kerugian (Kerzner, 1995). Risiko merupakan konsekuensi atau bahaya yang berpeluang dapat terjadi karena adanya suatu proses yang sedang berlangsung atau akan berlangsung.

Risiko adalah situasi ketidakpastian yang mana dapat terjadi jika suatu keadaan yang tidak dikehendaki sehingga menimbulkan kerugian (Hanafi, 2006). Risiko juga didefinisikan sebagai efek dari ketidakpastian sasaran yang bias bersifat positif ataupun negatif, yang mana kemungkinan situasi tersebut dapat mengancam pencapaian tujuan serta sasaran sebuah organisasi ataupun individu (Airmic, 2010). Prinsip yang digunakan dalam alokasi risiko adalah bahwa risiko sebaiknya dialokasikan pada pihak yang lebih mampu untuk mengelolanya (Palupie, Y.M.R dan Yuniarto, H.A, 2016).

Menurut Loosemore (2007), risiko-risiko ini berpontensi mempengaruhi proyek KPBU yaitu risiko kridit (berhubungan dengan arus pembayaran hutang obligasi), risiko konstruksi (yang berhubungan dengan periode penyelesaian konstruksi), risiko penerimaan (yang berhubungan dengan arus penerimaan), risiko operasi (yang berhubungan dengan pemeliharaan dan penggantian), dan risiko keuangan dan hukum (yang berhubungan dengan kecukupan dan sensitifitas arus uang terhadap pengembalian hutang). Sedangkan Grimsey and Lewis (2004) mengidentifikasi enam risiko yang berhubungan dengan proyek KPBU, yaitu risiko umum (yang berhubungan dengan tanggung jawab pemerintah yang menjamin bahwa konstruksi sesuai dengan peraturan), risiko aset (yang berhubungan dengan biaya pemeliharaan yang melebihi dari rencana akibat kerusakan oleh kejadian force majeur), risiko operasi (yang berhubungan dengan ketidaksesuaian spesifikasi, biaya, atau waktu dengan kesepakatan), risiko sponsor (yang berhubungan dengan ketidaksanggupan pemerintah menyelenggarakan obligasi perjanjian atau menutupi kompensasi), risiko keuangan (yang berhubungan dengan harga dan biaya meningkat, penarikan pemilik modal, dan diskonto meningkat), dan risiko kegagalan (yang berhubungan dimana satu pihak tidak sanggup menyelenggarakan obligasi perjanjian). Faktor risiko menurut PT PII sebagai berikut:

a. Risiko lokasi meliputi risiko pembebasan lahan, risiko ketidaksesuaian lokasi lahan, risiko lingkungan dan risiko terkait lokasi yang tak terduga.

b. Risiko desain, konstruksi dan uji operasi meliputi risiko perencanaan, desain, penyelesaian, kenaikan biaya dan risiko uji coba.

c. Risiko sponsor merupakan risiko pada saat kewajiban badan usaha kepada PJPK tidak dapat dipenuhi akibat investor sebagai sponsor proyek, badan udaha yang gagal memenuhi persyaratan lender serta pinjaman yang gagal disediakan oleh lender. 
d. Risiko finansial meliputi risiko ketidakpastian pembiayaan, risiko parameter finansial, risiko struktur finansial dan risiko asuransi.

e. Risiko operasi meliputi risiko cacat tersembunyo, utilitas, teknologi, sumber daya, pemeliharaan serta hubungan industri.

f. Risiko pendapatan meliputi risiko permintaan dan risiko tarif.

g. Risiko konektivitas jaringan meliputi risiko pengembangan jaringan, risiko konektivitas dengan jaringan eksisting dan risiko fasilitas pesaing.

h. Risiko interface merupakan risiko akibat terhalang atau terganggunya penyediaan layanan dan fasilitas infrastruktur akibat metode impelmentasi proyek oleh pihak terkait atau akibat standar penyediaan layanan.

i. Risiko politik meliputi risiko pengambilalihan, risiko perubahan regulasi dan perundangan, risiko mata uang yang tidak dapat dikonversi, risiko subsovereign atau parastatal, risiko perubahan tarif pajak dan risiko perizinan.

j. Risiko force majeure merupakan risiko terjadinya kejadian tidak terduga (kahar) yang terjadi di luar kendali dari pihak-pihak terkait.

k. Risiko kepemilikan aset merupakan risiko terjadinya perubahan teknologi, kehilangan, atau hal lainnya yang berakibat pada penurunan asset.

I. peristiwa seperti kejadian kehilangan, perubahan teknologi dan lainnya baik selama atau pada akhir masa kontrak yang menyebabkan nilai ekonomi aset menurun.

Beberapa fasilitas pendukung program KPBU yang disediakan oleh pemerintah meliputi:(1) fasilitas penyiapan proyek dan (2) dukungan kelayakan dan/atau penjaminan pemerintah. Dalam hal ini, pemerintah memberikan jaminan dalam bentuk pinjaman atas risiko politik (Suhendra, M, 2017).

\subsection{Analisis Deskriptif dan Three Box Method}

Analisis deskriptif merupakan metode untuk menggambarkan data sebagaimana adanya (Sugiyono, 2005). Pada penelitian ini digunakan analisis indeks yang mengambarkan jawaban responden atas item pernyataan pada kuesioner yang diajukan. penilaian dilakukan menggunakan skala likert dengan rentang 1 sampai 5. Skala likert merupakan teknik untuk mengkuantifikasi tanggapan responden terhadap penyataan yang bersifat kualitatif. Perhitungan nila rata-rata dilakukan pada Persamaan 1 sebagai berikut (Likert, 1932):

$$
\bar{X}=\frac{x_{1}+x_{2}+\cdots+x_{n}}{n}
$$

dengan:

$\bar{X} \quad=$ nilai rata-rata;

$x_{1}, x_{2} \ldots=$ nilai responden ke $1,2 \ldots$;

$n \quad=$ jumlah responden.

Nilai angka indeks dihitung pada Persamaan 2 sebagai berikut:

dengan:

$$
N I=\frac{\left[\left(\% F_{1} \times 1\right)+\left(\% F_{2} \times 2\right)+\left(\% F_{3} \times 3\right)+\left(\% F_{4} \times 4\right)+\left(\% F_{5} \times 5\right)\right]}{5}
$$

NI $\quad$ nilai indeks,

$F_{1}, F_{2}, F_{3}, F_{4}, F_{5}=$ banyaknya responden yang menjawab $1,2,3,4,5$ dari skor yang digunakan dalam daftar kuesioner.

Analisis data dilakukan dengan tujuan untuk menjelaskan karakteristik responden yang diperoleh dari data. Pada three box method ditentukan batas bawah dan batas atas skala 
penilaian kuesioner. Adapun nilai batas bawah dan batas atas dihitung pada Persamaan 3 dan Persamaan 4 sebagai berikut:

$$
\begin{aligned}
& \text { batas atas }=\frac{\% F \times 5}{5} \\
& \text { batas bawah }=\frac{\% F \times 1}{5}
\end{aligned}
$$

Selanjutnya, three box method membagi data menjadi tiga bagian sehingga menghasilkan tiga rentang pada masing-masing katagori yaitu rendah, sedang dan tinggi.

\section{METODOLOGI}

Penelitian ini menilai besarnya risiko KPBU pada sektor jalan tol. Penilaian risiko KPBU dilakukan pada tiga fase proyek pembangunan jalan tol yaitu fase prakosntruksi, konstruksi serta operasi dan pemeliharaan jalan tol. Penilaian faktor risiko dilakukan pada seluruh variabel (11 variabel) dimana setiap fase memiliki faktor risiko yang berbeda. Setelah penilaian risiko dilakukan, langkah selanjutnya dilakukan analisis statistik dan three-box method. Hasil analisis ini berupa tingkat faktor risiko KPBU jalan tol yang terdiri dari tiga tingkatan (tinggi, sedang dan rendah). Dalam hal ini, penentuan langkah mitigasi akan dilakukan pada faktor-faktor dengan risiko tinggi. Adapun Kerangka Penelitian dan Tahapan Penelitian disampaikan pada Gambar 1 dan Gambar 2. 


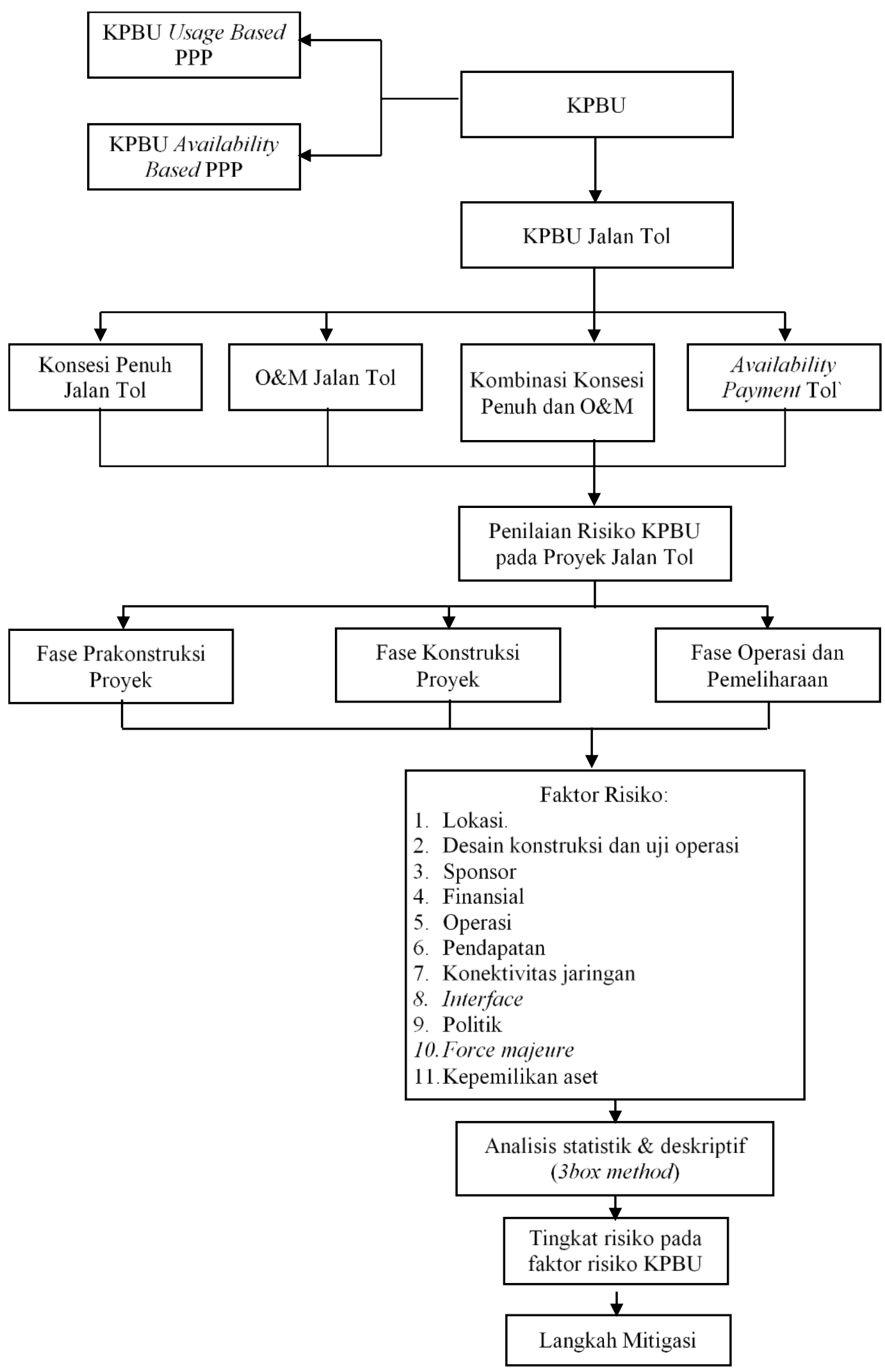

Gambar 1. Kerangka penelitian 


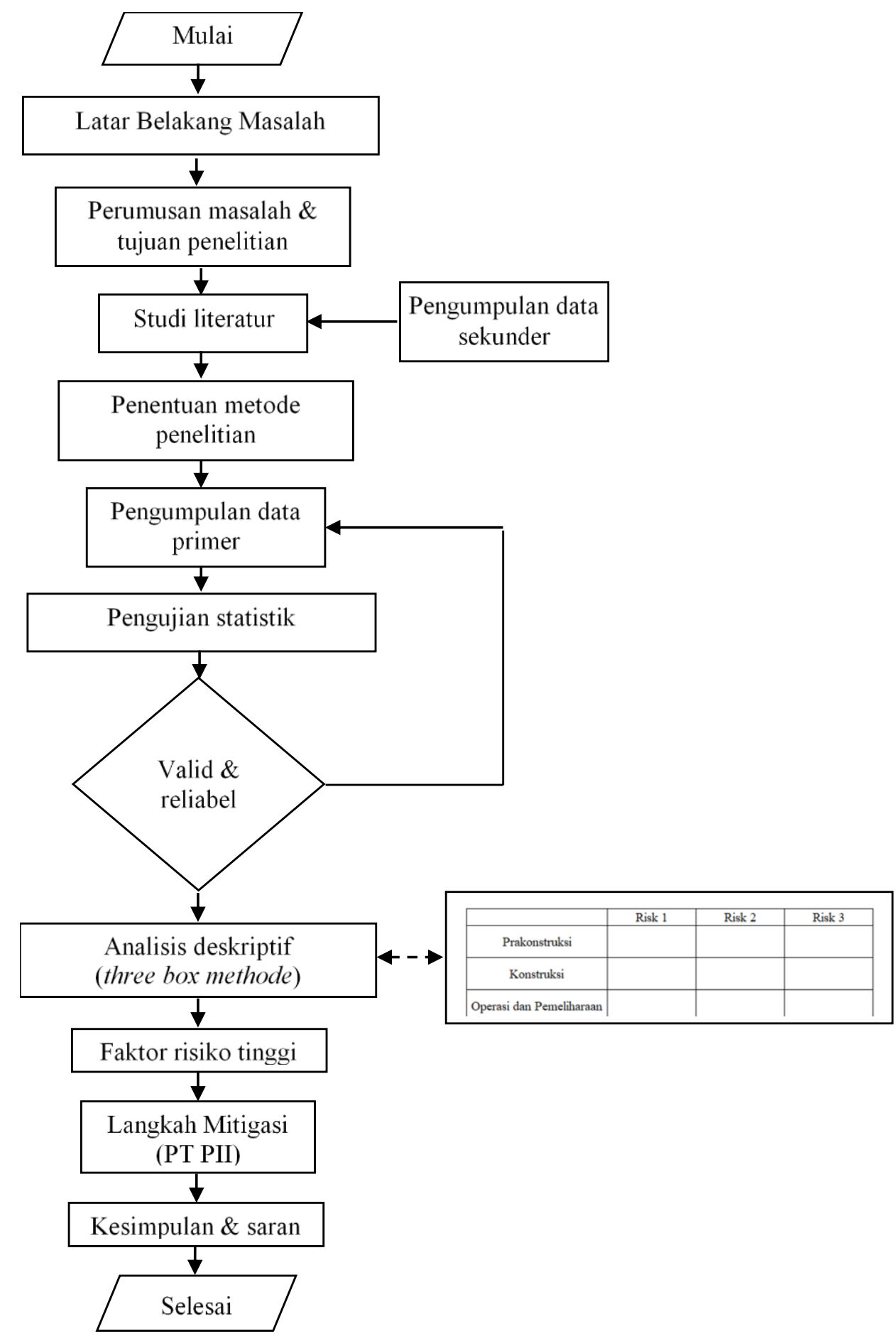

Gambar 2. Tahap penelitian

4. ANALISIS DAN PEMBAHASAN

\subsection{Data Responden}

Pengambilan data dilakukan dengan mendistribusikan kuesioner secara online kepada 32 responden. Responden penelitian merupakan pegawai perusahaan pengadaan jalan tol yang memiliki jabatan setingkat manajer. Responden berasal dari beberapa perusahaan pengaturan jalan tol dan perusahaan konstraktor yang terlibat dalam pembangunan jalan tol. Kuesioner berisi penyataan terhadap 11 variabel faktor risiko dengan 70 indikator. 


\subsection{Analisis Three Box Method}

Batas atas dan batas bawah ditentukan sebagai berikut:

$$
\text { batas atas }=\frac{\% F \times 5}{5}=\frac{32 \times 5}{5}=32,0 \quad \text { batas bawah }=\frac{\% F \times 1}{5}=\frac{32 \times 1}{5}=6,4
$$

Berdasarkan batas-batas tersebut; diperoleh rentang sebesar 25,6. Selanjutnya dengan menggunakan three box method, dibagi menjadi 3 sebagai berikut:

1. $23,48 \leq \mathrm{x} \leq 32,00 \quad$ Katagori risiko tinggi

2. $14,93 \leq x \quad 23,48 \quad$ Katagori risiko sedang

3. $6,40 \leq \mathrm{x} \leq 14,93 \quad$ Katagori risiko rendah

Selanjutnya dilakukan rekapitulasi penilaian responden terhadap indikator-indikator pada masing-masing faktor risiko. Hasil perhitungan frekuensi disampaikan pada Tabel 1.

Tabel 1. Indeks Risiko

\begin{tabular}{clcccccc}
\hline \multirow{2}{*}{ No } & \multirow{2}{*}{ Faktor Risiko } & \multicolumn{2}{c}{ Prakonstruksi } & \multicolumn{2}{c}{ Konstruksi } & \multicolumn{2}{c}{ O\&M } \\
\cline { 3 - 7 } & & $\begin{array}{c}\text { Indeks } \\
\text { Risiko }\end{array}$ & $\begin{array}{c}\text { Katagori } \\
\text { Risiko }\end{array}$ & $\begin{array}{c}\text { Indeks } \\
\text { Risiko }\end{array}$ & $\begin{array}{c}\text { Katagori } \\
\text { Risiko }\end{array}$ & $\begin{array}{c}\text { Indeks } \\
\text { Risiko }\end{array}$ & $\begin{array}{c}\text { Katagori } \\
\text { Risiko }\end{array}$ \\
\hline 1 & Lokasi & 22,80 & Sedang & 21,94 & Sedang & 23,30 & Sedang \\
\hline 2 & Desain, konstruksi, uji op. & 24,20 & Tinggi & 22,90 & Sedang & 0,00 & - \\
\hline 3 & Sponsor & 22,87 & Sedang & 22,87 & Sedang & 22,87 & Sedang \\
\hline 4 & Finansial & 23,55 & Tinggi & 23,92 & Tinggi & 24,07 & Tinggi \\
\hline 5 & Operasi & 21,60 & Sedang & 21,27 & Sedang & 22,02 & Sedang \\
\hline 6 & Pendapatan & 0,00 & - & 0,00 & - & 21,89 & Sedang \\
\hline 7 & Konektivitas jaringan & 0,00 & - & 0,00 & - & 22,00 & Sedang \\
\hline 8 & Interface & 22,60 & Sedang & 22,67 & Sedang & 22,60 & Sedang \\
\hline 9 & Politik & 22,33 & Sedang & 22,54 & Sedang & 22,40 & Sedang \\
\hline 10 & Force majeure & 22,47 & Sedang & 22,47 & Sedang & 22,47 & Sedang \\
\hline 11 & Kepemilikan aset & 0,00 & - & 0,00 & - & 23,67 & Tinggi \\
\hline
\end{tabular}

\subsection{Matriks Risiko KPBU Jalan Tol}

Matriks risiko merupakan kumpulan dari beberapa indeks risiko yang telah dianalisis sebelumnya. Nilai matriks risiko diperoleh dengan three box method dengan hasil seperti disampaikan pada Tabel $\mathbf{2}$.

Tabel 2. Matriks Risiko KPBU Jalan Tol

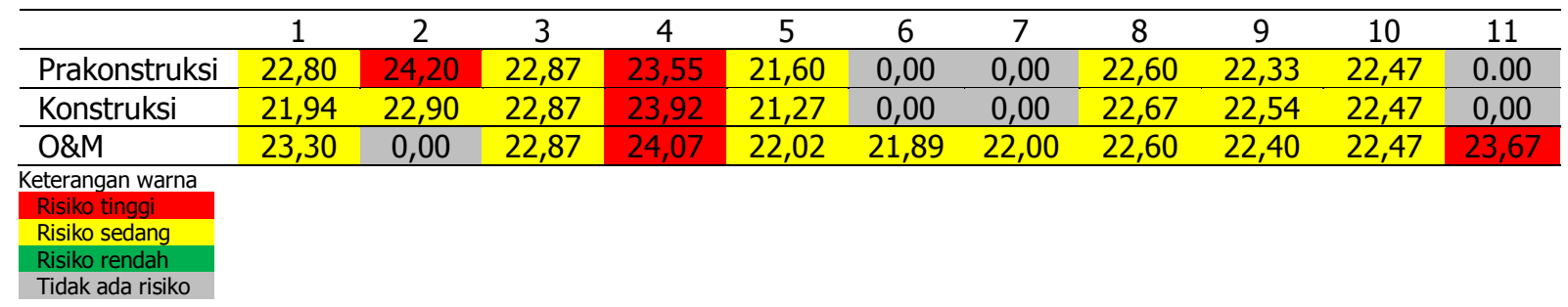

Berdasarkan matriks risiko pada Tabel 2, diperoleh hasil sebagai berikut:

1. Pada fase prakonstruksi, faktor desain, konstruksi dan uji operasi serta finansial merupakan variabel yang memiliki risiko tinggi. 
Risiko desain, konstruksi dan uji operasi melibatkan indikator kesalahan desain yang pada akhirnya akan menyebabkan eksra revisi pada desain yang dimintakan baik oleh operator atau badan usaha. Beban pengalokasian risiko ini kemungkian besar nantinya akan diterima oleh phak badan usaha atau operator jalan tol. Untuk mengurangi atau menghindari risiko, hendaknya badan usaha melakukan proses tender pekerjaan dengan baik dan cermat dalam memilih konsultan engineering. Dalam hal ini diperlukan konsultan desain ataupun EPC yang sudah memiliki pengalaman dan rekam jejak pekerjaan yang baik serta handal dalam menyelesaikan pekerjaan desain.

Risiko finansial berkaitan dengan indikator kenaikan inflasi terhadap asumsi dalam life cycle cost dan suku bunga serta nilai tukar mata uang. Risiko ini kedepannya akan banyak ditanggu oleh badan usaha. Jika nilai inflasi terlalu ekstrim maka risiko ini dibagi dengan pemerintah. Mitigasi yang dapat dilakukan meliputi pembiayaan proyek dengan mata uang lokal dan penggunaan instrumen lindung nilai berupa kontrak berjangka ataupun opsi mata uang. Selain itu, penggunaan indeks harga pembelian dengan memperhitungkan fluktuasi mata uang juga dapat mengurangi beban risiko terkait fluktuasi nilai tukar mata uang.

2. Pada fase konstruksi, faktor risiko finansial merupakan faktor dengan risiko tinggi. Faktor ini berkaitan dengan indikator kenaikan inflasi dan nilai rukar mata uang. Langkah mitigasi yan gdapat dilakukan sama seperti pada fase prakonstruksi. Selain itu, risiko finansial pada fase ini melibatkan indikator adanya risiko keterlambatan penggantian dana talangan oleh pemerintah. Dalam hal ini, langkah mitigasi yang dapat dilakukan yaitu perlunya kepastian adanya dana BLU dengan kepastian penambahan dana dari APBN jika sudah mencapai batas tertentu.

3. Pada fase $\mathrm{O} \& M$, faktor risiko finansial dan risiko kepemilikan aset merupakan faktor dengan risiko tinggi. Sama seperti fase sebelumnya, risiko finansial berkaitan dengan indikator kenaikan inflasi dan nilai tukar mata uang. Dalam hal ini, langkah mitigasi yang dapat dilakukan sama dengan fase sebelumnya.

Risiko kepemilikan aset berkaitan dengan indikator adanya kendala transfer aset setelah kontrak berakhir karena perbedaan mekanisme pengalihan atau penilaian. Risiko ini akan menjadi bebab badan usaha sebagai pihak yang telah mengoperasikan jalan tol sesuai jangka waktu yang telah ditetapkan. Langkah mitigasi yang dapat dilakukan dengan membuat kontrak diawal proyek yang juga mengatur perihal transfer aset secara detail dan jelas. selain itu mitigasi dilakukan dengan menunjukk penilai independent dari pihak ketiga yang garus disepakati bersama.

\section{KESIMPULAN}

Berdasarkan hasil analisis diperoleh kesimpulan sebagai berikut:

1. Proyek pekerjaan jalan tol dengan enggunakan skema KPBU memiliki risiko yang terdistribusi berbeda-beda untuk setiap tahap proyek yaitu prakonstruksi, konstrksi sertaoperasi dan pemeliharaan (O\&M). Faktor risiko finansial merupakan faktor risiko dengan kategori risiko tinggi yang selalu muncul pada setiap fase proyek tersebut.

2. Beberapa langkah perlu dilakukan untuk meminimalkan risiko yang terjadi, antara lain:

a. faktor risiko finansial memerlukan mitigasi sebagai berikut:

- $\quad$ faktor indeksasi tarif dan lindung nilai tingkat suku bunga

- pembiayaan dalam mata uang lokal

- $\quad$ fluktuasi mata uang memperhitungkan indeks harga pembelian

RekaRacana - 30 
- $\quad$ instrumen lindung nilai, diantaranya konstrak berjangka dan opsi mata uang

- $\quad$ kepastian ketersediaan dana BLU tanah dengan kepastian penambahan dana dari APBN jika sudah mencapai batas tertentu

b. Faktor risiko desain, konstruksi dan uji operasi yang muncul di fase prakonstruksi memerlukan mitigasi berupa memilih konsultan desain ataupun perusahaan EPC yang sudah memiliki pengalaman dan rekam jejak pekerjaan yang baik serta handal dalam menyelesaikan pekerjaan desain.

c. Faktor risiko kepemilikan aset yang muncul di fase operasi dan pemeliharaan memiliki langkah mitigasi pembuatan konstrak yang mengatur perihal transfer aset dengan jelas dan memilih perihal independen yang disepakai bersama untuk melakukan penilaian secara transparan.

\section{DAFTAR RUJUKAN}

Airmic, A. (2010). A Structured Approach to Enterprise Risk Management (ERM) and Requirement of ISO 31000. ERM.

Hanafi, M. (2006). Manajemen Risiko. Yogyakarta: UPP STIM YKPN

Grimsey D., Lewis M. K. (2004). Public Private Partnership:The Worldwide Revolution in Infrastructure Provision and Private Finance, Cheltenham, UK.

Kerzner, H. (1995). Project Management A System Approach to Planning, Scheduling, and Controlling, An International Thomson Publishing Company, USA.

Likert, R. (1932). A Technique for the Measurement of Attitude. New York: New York University Loosemore, M. (2007) Risk Allocation in The Private Provision of Public Infrastructure, International Journal of Project Management, Vol. 25, p 66-76.

Maramis, J. B. (2018). Faktor-faktor Sukses Penerapan KPBU Sebagai Sumber Pembiayaan Infrastruktur: Suatu Kajian. Jurnal Manajemen Bisnis dan Inovasi.

Palupie, Y.M.R \& Yuniarto, H. A. (2016). Alokasi Risiko Proyek Infrastruktur Dengan Skema Kerjasama Pemerintah dan Badan Usaha (KPBU): Suatu Tinjauan Literatur. Yogyakarta: UGM.

Peraturan Presiden No. 38 Tahun 2015 tentang Kerjasama Pemerintah Dan Badan Usaha Dalam Penyediaan Infrastruktur.

PT. PII. (2017). Acuan Alokasi Risiko KPBU di Indonesia. Jakarta: PT Penjaminan Infrastruktur Indonesia.

Riyanda, I. (2020). Pemeriksaan Kinerja BPK RI Atas Perjanjian Skema Kerjasama Pemerintah Dengan Badan Usaha (KPBU). Bandar Lampung: BPK.

Sugiyono. (2005). Memahami Penelitian Kualitatif. Bandung: CV Alfabeta

Suhendra, M. (2017). Penyediaan Infrastruktur Dengan Skema Kerjasama Pemerintah dan Badan Usaha (Public-Private Partnership) di Indonesia. Jurnal Manajemen Keuangan Publik.

Syamshabrina, A. S dan Ariastita, P. G. (2017). Preferensi Pemerintah dan Badan Usaha Dalam Pengembangan Lyn Sebagai Angkutan Umum Feeder di Surabaya Melalui Skema KPBU. Surabaya: ITS.

Yusuf, A. (2018). Kebijakan Penyediaan Infrastruktur dengan Mekanisme Kerjasama Pemerintah dan Badan Usaha (KPBU). Yogyakarta: UIN Sunan Kalijaga 